\title{
Dark Triad Personality Dimensions: A Literature Review in Career Choice
}

\author{
Jian-zhong Hong* and Alemayehu Belay Emagnaw \\ School of Psychology, Central China Normal University, China \\ Submission: June 10, 2019; Published: July 30, 2019 \\ ${ }^{*}$ Corresponding author: Jian-zhong Hong, School of Psychology, Central China Normal University, China
}

\begin{abstract}
The concept of Dark Triad (DT) has emerged as an important determinant of a career choice. Several researches have been conducted on DT, but a few studies are in the career choice. However, considering the contributions of DT in the recent times, a more comprehensive review is attempted here on career choice. In this connection, the author has reviewed the literature on DT components which would help researchers to take a closer look at the application of DT components. For this purpose, the author considered available secondary data relates to career choice. The present paper Dark Triad Personality Components: A Literature Review in career choice, is presented in four parts encompassing the concept of DT, Review of available Literature on DT, various components of DT and adoption of DT components to career choice. Based on the review a conclusion is provided. It is observed that three components are most predominant dimensions that address the DT of employees in the career choice.
\end{abstract}

Keywords: Dark Triad (DT); Machiavellianism; Narcissism; Psychopathy and Career Choice

\section{Introduction}

The Dark Triad personality has become an interesting research area in the field of psychology since its introduced in 2002 by Paulhus \& Williams [1]. The Dark Triad is a set of adverse personality traits, described as being abnormal behavior, pathological, and immoral values [2]. The term 'dark' refers to the maladaptive tendencies possessed by undesirable personality traits. Organizational Psychologists have often thought over what makes people choose certain careers. This is also something individuals consider themselves when looking to make a career change. Tokar et al. [3] reported that personality is one of the key factors behind career choice. The dark triad has produced a lot of interest amongst researchers. Jones \& Figueredo [4] found that the Dark Triad consists of three overlapping but distinct personality traits: narcissism, machiavellianism and psychopathy. According to Jonason, et al. [5] different personalities tend to be attracted to certain types of careers and away from others. This begs the question, what kind of occupations attract those who score high in the dark triad? The following will provide an overview of the Dark Triad and will examine Narcissism, Machiavellianism and Psychopathy separately in order to determine if each trait impacts career choices.

Dark Triad personality consisted of three traits. These are: narcissism, psychopathy and Machiavellianism. The three dimensions of the Dark Triad personality are inter-correlated; however, each trait holds their own distinctive behavioral, cognitive, and personality qualities [1]. Furthermore, Jones \& Paulhus [6] claim that the sub-clinical forms of Machiavellianism, narcissism and psychopathy share a variety of features like coldness, manipulation and self-centeredness. In the context of this review, all three of the Dark Triad traits will be shortly discussed.

\section{Dark Triad Personality Dimensions}

\section{Narcissism}

The construct of narcissism is normally based on a legend in Greek mythology. One of the first used scholars of narcissism concept was Havelock Ellis in 1898. It is difficult to define narcissism because it is studied in different disciplines such as social-personality, clinical psychology and psychiatry [7]. Clinical psychology and psychiatry consider narcissism as a personality disorder whereas in social psychology, narcissism is mainly considered at sub-clinical level. Narcissism is defined by excessive self-admiration, and the need for authority and superiority over others. Narcissists exhibit an excessive ego and show selfish behavior. On a conceptual level, the main facets of the Narcissistic Personality Inventory (NPI) include grandiosity, entitlement, dominance, and superiority [1].

According to Ritter et al. [8], Narcissism personality is characterized by a lack of empathy as well as a pattern of grandiosity and overwhelming need for admiration. Campbell \& 
Campbell [7] explained that although narcissists lack empathy and have very few close relationships, they will seek social contact with other people as a means of gaining admiration and attention. Narcissists are grandiose self-promoters who strive for admiration from others [6].

\section{Machiavellianism}

The term Machiavellianism originates from Niccolo Machiavelli, the infamous political philosopher of the Renaissance [9]. Machiavelli is mostly known for his book The Prince, expressing his perspectives on the ruthlessness and callousness that is required of a powerful ruler, whereby the immorality and indecency of one's actions would be condoned by the grandiosity and success that one gains. Thus, giving name for those who possess immoral mechanisms, using deception, exploitation and manipulation for personal gain.

According to Paulhus [6], Machiavellians are master manipulators, pursuing a long-term oriented calculated social manipulation. Machiavellianism is defined by manipulative and deceitful behaviors, distrustfulness, and motivated by self-interest $[1,9]$. People high in Machiavellianism are malevolent, vindictive, and pragmatic, seeking only to win, and disregarding whatever the cause [10]. As Hawley [11] notes, Machiavellians are "coercive controllers" with an adaptive combination of pro and antisocial tactics to best achieve their career-success related goals. Machiavellians are cynical, tactical, and believe in interpersonal manipulation as the key for life success [12]. They are cold-hearted and callous, and their primary motivation lies in obtaining money, power, and status.

\section{Psychopathy}

The term psychopath, deriving from psych meaning the soul and pathy meaning disease or suffering, was introduced by the German psychiatrist, J.L.A Koch $[7,13]$. In a previous study, psychopathic individuals were found to be pragmatic in their decisions-making and present no emotional or meaningful factor. They focus only on what benefits them. Primary psychopathy will reuse previously discussed information with the intention to exploit others for personal gain.

They are oblivious to the risks or potential social ad personal consequences of their actions, do not learn from their mistakes and given its immoral and malevolent nature, psychopathy is deemed the darkest amongst the DT personalities [1]. Psychopathy is defined by impulsiveness, a disregard towards others, and an absence of remorse and empathy.

\section{DT Components in Career Choice}

Westerman [14] investigated whether narcissism is influencing student salary and career expectations. Westerman [14] found that narcissism is still growing amongst business majors today and doesn't seem to be declining. In addition, expressed concerns about why business schools seem to be attracting more and more narcissistic graduates. The research questioned if schools are encouraging students to embrace their inner narcissistic traits. compared business to psychology students and found that the business students displayed higher levels of narcissism than psychology students. These findings suggest that narcissists are highly attracted to the business and management sector. Concluded that if colleges are encouraging this, it will likely have a significant impact on businesses, the economy, and our environment.

Narcissistic tendencies have been shown to positively associate with objective indices of professional success such as hierarchical position and financial achievement $[15,16]$ as well as with subjective career satisfaction [15]. This might also be explained by narcissists' high self-efficacy beliefs, high career engagement, and high self-esteem. When common variance with the other DT traits, age, gender, education, employment degree, work tenure and organization size were controlled for, narcissism was still significantly related to salary [16].

Dahling et al. [17] was developed and validated a new measure of Machiavellianism, the Machiavellian Personality Scale (MPS), over two studies. Machiavellianism is conceptualized as one's propensity to distrust others, engage in amoral manipulation, seek control over others, and seek status for oneself. Study 1 developed and tested the factor structure of the scale, whereas Study 2 provided evidence for the convergent, divergent, and criterionrelated validity of the MPS. The results of these studies indicated that it is a valid predictor of such outcomes as job satisfaction, task performance, and counterproductive work behaviors. Machiavellians are likely to choose careers which, provide access to extensive resources and means of controlling others [17].

Machiavellianism has been found beneficial for attaining leadership positions [16,17], possibly because Machiavellians tend to focus on maintaining and broadening power by using manipulative behaviors, strive for control, and have a desire for status [17]. Contradictory findings link Machiavellianism with job satisfaction. The Machiavellianism-job performance relation was small and not particularly consistent, while the MachiavellianismCWB relation was more robust and consistent. Furthermore, organizational variables did not moderate the negative effects of Machiavellianism: Machiavellians were less productive and more likely to engage in negative workplace behaviors regardless of their level of authority or the degree of collectivism in the organization where they worked. Leaders' Machiavellianism has detrimental effects on subordinates' career success and wellbeing, including their job satisfaction [18].

Dutton [19] proposed that society needs psychopathy whether they realize it or not. There is a misconception amongst the public that psychopaths are just criminals and murderers. However, Dutton [19] argues that the psychopathic traits, such as charm, confidence, ruthlessness and coolness under pressure can be a good thing, provided they are in the right doses. The study reported that just because the psychopath has the trait of boldness, this does not mean they will end up as killers. In fact, it can lead to heroic acts. Found that the psychopath has the ideal personality 
to become a surgeon or a bomb disposal expert. Ironically, Dutton [19] also found that some psychopaths are working as prison guards locking up other people. Therefore, based on the research, it is fair to say that not all psychopaths end up as criminals, a lot of them are quite successful.

Empirical findings link psychopathy with hierarchical position and financial achievement, with some showing positive links and they earn low salaries and experience poor objective and subjective professional success [16]. Among the three Dark Triad features, psychopathy has been shown to be the strongest predictor of "cutting corners" at work [5]. When common variance with the other Dark Triad traits and socio-demographic and organizational variables were accounted for, the negative links between psychopathy and low objective and subjective indicators of career success remained significant [16]. These effects might be due to their high impulsivity and low conscientiousness $[1,16]$. Again, however, some researchers show that psychopathic fearless dominance is positively linked to subjective and objective professional success [20].

\section{Conclusion}

It can be seen from the above-mentioned studies conducted in various organizational settings in career choices more specifically in different countries and cultural background clearly evidenced that Dark Triad Personality dimensions have implications at career choice. The studies stoutly substantiated the relevance of Dark Triad Personality in honing career choices behavior and attitudes like job satisfaction, organizational commitment, reduced absenteeism and employee well-being, engagement in job and even improved performance. Hence, it can be concluded that Dark Triad Dimensions triggers positive workplace experiences in employees, academicians in specific. It can be concluded that even to career choices, the following three components are most predominant components that address the Dark Triad Personality of employees. They are Narcissism, Machiavellianism and Psychopathy.

\section{References}

1. Delroy L Paulhus, Kevin M Williams (2002) The Dark Triad of Personality: Narcissism, Machiavellianism, and Psychopathy. Journal of research in personality 36(6): 556-563.

2. Kowalski Robin M (2001) Behaving Badly: Aversive Behaviors in Interpersonal Relationships. Washington, DC: American Psychological Association. USA.

3. David M Tokar, Ann R Fischer, Linda Mezydlo Subich (1998) Personality and vocational behavior: A selective review of the literature, 19931997. Journal of Vocational Behavior 53(2): 115-153.
4. Daniel Nelson Jones, Aurelio Jose Figueredo (2013) The core of darkness: Uncovering the Heart of the Dark Triad. European Journal of Personality 27(6): 521-531.

5. Peter K Jonason, Peter J O'Connor (2017) Cutting corners at work: An Individual differences Perspective. Personality and Individual Differences 107: 146-153.

6. Delroy L Paulhus (2014) Toward a Taxonomy of Dark Personalities. Current Directions in Psychological Science 23(6): 421-426.

7. W Keith Campbell, Brian J Hoffman, Stacy M Campbell, Gaia Marchisio (2010) Narcissism in Organizational Contexts. Human Resource Management Review 21(4): 268-284.

8. Ritter K, Dziobek I, Preissler S, Rüter A, et al. (2011) Lack of Empathy in Patients with Narcissistic Personality Disorder. Psychiatry research, 187(1), 241-247.

9. Festinger L, Schachter S (2013) Studies in Machiavellianism. Academic Press. New York.

10. Danilo Garcia, Lillemor Adrianson, Trevor Archer (2015) The Dark Side of the Affective Profiles: Differences and Similarities in Psychopathy, Machiavellianism, and Narcissism. SAGE Open 5(4).

11. Patricia H Hawley (2003) Prosocial and Coercive Configurations of Resource Control in early Adolescent: a Case for the well-Adapted Machiavellian. Journal of Development Psychology 49: 279-309.

12. Furtner MR, Baldegger U (2016) Self-Leadership und Führung: Theorien, Modelle und praktische Umsetzung (2. Auflage) [Self-leadership and leadership: theories, models, and practical application $\left(2^{\text {nd }}\right.$ edition)]. Wiesbaden: Springer Gabler. Europe.

13. Kent A Kiehl, Kent A Kiehl (2011) The criminal psychopath: History, Neuroscience, Treatment, and economics. Jurimetrics 51: 355-397.

14. James W Westerman, Jacqueline Z Bergman, Shawn M Bergman (2012) Are Universities Creating Millennial Narcissistic Employees? An Empirical Examination of Narcissism in Business Students and its Implications. Journal of Management Education 36(1): 5-32.

15. Andreas Hirschi, Vanessa K Jaensch (2015) Narcissism and Career Success: Occupational self-efficacy and Career Engagement as Mediators. Personality and Individual Differences 77: 205-208.

16. Daniel Spurk, Anita C Keller, Andreas Hirschi (2016) Do bad guys get ahead or fall behind? Relationships of the dark triad of personality with objective and subjective career success. Social Psychological and Personality Science 7: 113-121.

17. Jason J Dahling, Brian G Whitaker, Paul E Levy (2008) The Development and Validation of a New Machiavellianism Scale. Journal of Management 35(2): 219-257.

18. Judith Volmer, Iris K Koch, Anja S Göritz (2016) The Bright and Dark Sides of leaders' Dark Triad Traits: Effects on subordinates' career success and well-being. Personality and Individual Differences 101: 413418.

19. Dutton K (2012) The wisdom of Psychopaths. Scientific American 307(4): 76-79.

20. Hedwig Eisenbarth, Claire M Hart, Constantine Sedikides (2018) Do Psychopathic Traits Predict Professional Success? Journal of Economic Psychology 64: 130-139. 
This work is licensed under Creative Commons Attribution 4.0 License DOI: 10.19080/ASM.2019.03.555624

\section{Your next submission with Juniper Publishers} will reach you the below assets

- Quality Editorial service

- Swift Peer Review

- Reprints availability

- E-prints Service

- Manuscript Podcast for convenient understanding

- Global attainment for your research

- Manuscript accessibility in different formats

( Pdf, E-pub, Full Text, Audio)

- Unceasing customer service

Track the below URL for one-step submission https://juniperpublishers.com/online-submission.php 